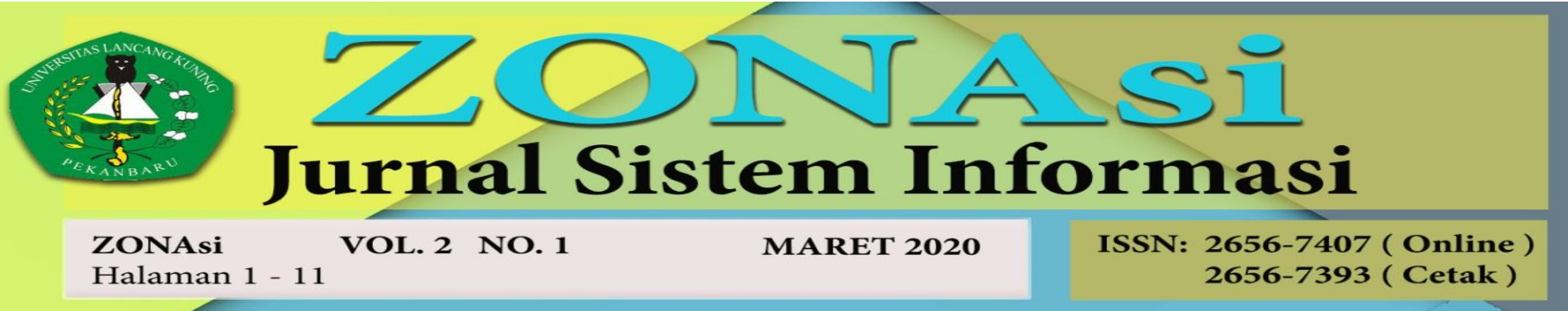

\title{
SISTEM INFORMASI KESELAMATAN DAN KEAMANAN \\ DI KAWASAN BANDARA PADA DINAS SAFETY \& RISK \\ PT. ANGKASA PURA II BANDARA INTERNASIONAL MINANGKABAU
}

\author{
Nelfira $^{1}$, Arief Rahmadian Aswin ${ }^{2}$, Elizamiharti ${ }^{3}$, Afif Gaziafi $^{4}$ \\ Program Studi Sistem Informasi STMIK Indonesia \\ Jl. Khatib Sulaiman Dalam No. 1, Padang \\ Email: nelfira@stmikindonesia.ac.id ${ }^{1}$, ariefrahmadian@ stmikindonesia.ac.id ${ }^{2}$, \\ elizamiharti@stmikindonesia.ac.id ${ }^{3}$, afifgazali@stmikindonesia.ac.id ${ }^{4}$
}

\begin{abstract}
ABSTRAK
Penelitian ini dilakukan pada kantor Dinas Safety \& Risk PT. Angkasa Pura II cabang Bandara Internasional Minangkabau. PT. Angkasa Pura II mendukung terciptanya aspek keselamatan dan keamanan selama di kawasan Bandara. Permasalahan yang ditemukan pada saat penelitian yaitu pemeriksaan keselamatan dan keamanan masih menggunakan formulir ceklist, sehingga pemeriksaan keselamatan dan keamanan menjadi tidak efisien dan efektif. Petugas Safety \& Risk mengalami kesulitan dalam pengecekan masa berlaku PAS Bandara dan petugas mengalami kesulitan dalam melakukan perbaikan data, serta belum adanya grafik. Untuk itu dirancang sebuah sistem yang dapat mempermudah petugas dalam melakukan pemeriksaan. Metode penelitian ini menerapkan metode berorientasi objek, bahasa pemrograman yaitu PHP dan MySQL sebagai database. Metode pengumpulan data dalam penelitian ini yaitu melalui wawancara dan observasi. Penelitian ini menunjukkan hasil bahwa sistem informasi keselamatan dan keamanan di kawasan bandara yang dirancang memudahkan petugas dalam melakukan pemeriksaan.
\end{abstract}

Kata Kunci: Sistem Informasi, keselamatan bandara, keamanan Bandara.

\section{ABSTRAK}

This research was conducted at the Office of Safety \& Risk of PT. Angkasa Pura II branch of Minangkabau International Airport. PT. Angkasa Pura II supports the creation of safety and security aspects during the Airport area. Problems found at the time of the research is the Safety \& Security Self Assessment examination is still using the checklist form so that safety and security checks become inefficient and effective, Safety \& Risk officers have difficulty in checking the validity of PAS Airport and officers have difficulty in doing data repair and yet the existence of the graph. For that designed a system that can facilitate the officer in conducting the examination. This research method apply object-oriented method, programming language that is PHP and MySQL as database. Data collection method in this research is through interview and observation. This study shows the result that the information system of Safety \& Security Self Assessment facilitate the officer in conducting examination.

Keywords: Information System, Safety, Security, Airport. 


\section{PENDAHULUAN}

Seiring pesatnya kemajuan teknologi informasi khususnya di bidang teknologi komputer menimbulkan implikasi yang sangat luas pada segala aspek kehidupan manusia dalam waktu yang relatif singkat. Pada saat ini, Dinas Safety \& Risk PT. Angkasa Pura II (Persero) Cabang Bandara Internasional Minangkabau masih menggunakan sistem pemeriksaan keselamatan dan keamanan secara manual yaitu dalam bentuk formulir ceklist. Sistem ini dianggap tidak efisien lagi mengingat jumlah data yang akan diambil cukup banyak dan tidak dapat disertai foto atau gambar saat pemeriksaan. Untuk mengatasi permasalahan tersebut diperlukan suatu sistem yang terkomputerisasi serta terintegrasi dengan baik memiliki database dan dapat diakses oleh petugas Dinas Safety \& Risk PT. Angkasa Pura II (Persero) Cabang Bandara Internasional Minangkabau.

Dengan dukungan sistem komputerisasi, dapat mengubah cara kerja yang lebih efisien, tepat guna dan berdaya guna serta terjamin mutu dan kualitas prosedur kerjanya. Dari ketentuan di atas dapat disimpulkan bahwa sistem komputerisasi merupakan langkah strategis yang akan diambil oleh pimpinan untuk mengembangkan perusahaannya dalam rangka mencapai kinerja yang efektif dan efisien. Jadi, hal ini akan sangat membantu sekali dalam menyelesaikan pekerjaan. Sistem kerja ini tentu akan mempermudah petugas dalam membuat laporan yang akan diberikan kepada pimpinan untuk menyusun strategi ke depan ataupun untuk mengambil keputusan.

Dinas Safety \& Risk pada PT. Angkasa Pura II merupakan sebuah dinas yang bertugas mendefinisikan dan menyusun standar operasional prosedur fungsi manajemen keselamatan dan resiko sesuai dengan standar dan regulasi yang berlaku pada PT.Angkasa Pura II. Namun dalam pemeriksaan keselamatan dan keamanan masih dilakukan secara manual seperti dalam pengambilan data menggunakan formulir ceklist yang diisi dengan tulis tangan dan formulir ceklist tersebut dijadikan sebagai laporannya, sehingga menimbulkan masalah apabila terjadi kesalahan dalam menginput data dan ingin mengubah data. Petugas Safety \& Risk kesulitan melakukan pencarian data karena tidak terintegrasi dengan baik serta tidak memiliki database, dan petugas kesulitan melakukan pengecekan masa berlaku pas bandara dan tidak adanya grafik yang menggambarkan keseluruhan data. Adapun komponen-komponen yang terdapat dalam formulir ceklist yaitu terdiri dari pemeriksaan, orang, kendaraan dan lokasi.

Berdasarkan permasalahan yang tersebut diatas yang dihadapi oleh PT. Angkasa pura II ini maka perlu di rancang sebuah system informasi keselamatan dan keamanan di kawasan Bandara Pada Dinas Safety \& Risk PT. angkasa Pura II Bandara Internasional Minangkabau yang efektif dan efisien. dan system yang dirancang dapat digunakan oleh pihak Bandara, dan juga dapat menudahkan pihak bandara dalam membuat laporan setiap saat dengan mudah dan tepat waktu. Selain itu dengan adanya aplikasi ini juga dapat digunakan untuk pemantauan perkembangan, peningkatan proses keselamatan dan keamanan di kawasan bandara.

\section{METODE PENELITAN}

\subsection{Instrumen Penelitian}

Instrumen penelitian yang digunakan adalah :

a. Observasi (pengamatan langsung)

Melakukan pengamatan langsung ke lokasi kantor PT. Angkasa Pura II (Persero)

Cabang Bandara Internasional Minangkabau khususnya pada Dinas Safety \& Risk untuk melihat lebih lanjut bagaimana proses sistem yang sedang berjalan. 


\section{b. Wawancara}

Melakukan wawancara dengan menemui langsung Junior Manager Safety \& Risk PT. Angkasa Pura II (Persero) Cabang Bandara Internasional Minangkabau.

\section{c. Penelitian Kepustakaan (Library Research)}

Penelitian ini mencari, membaca, mempelajari dan mengumpulkan referensi serta dasar teori yang diambil dari berbagai buku penunjang serta artikel-artikel yang berhubungan dengan penelitian yang dilakukan.

\subsection{Metodologi Berorientasi Objek}

Penelitian ini menggunakan metodologi Berorientasi Objek. Menurut Rosa dan Shalahuddin (2015:100) bahwa "Metodologi berorientasi objek adalah suatu strategi pembangunan perangkat lunak yang mengorganisasikan perangkat lunak sebagai kumpulan objek yang berisi data dan operasi yang diberlakukan terhadapnya. Metode berorientasi objek meliputi rangkaian aktivitas analisis berorientasi objek, perancangan berorientasi objek, pemrograman berorientasi objek, dan pengujian berorientasi objek."

a. Analisis Berorientasi Objek (Object Oriented Analysis)

Analisis berorientasi objek dimulai dengan menyatakan suatu masalah. Analis membuat model situasi dari dunia nyata dan menggambarkan sifat yang penting. Analis harus bekerja dengan pihak yang membutuhkan sistem untuk memahami masalah tersebut.

b. Desain Berorientasi Objek (Object Oriented Design)

Desain Berorientasi Objek atau Object Oriented Design (OOD) merupakan tahap lanjutan setelah analisis berorientasi objek dimana tujuan sistem diorganisasikan ke dalam subsistem berdasar struktur analisis dan arsitektur yang dibutuhkan. Mendesain sistem baru yang dapat menyelesaikan masalah-masalah yang dihadapi bidang Sistem Informasi keselamatan dan keamanan di kawasan bandara.

c. Pemrograman Berorientasi Objek

Menggunakan bahasa pemograman PHP untuk mendukung pemrograman berorientasi objek.

d. Pengujian Berorientasi Objek

Pada tahap ini, data yang telah selesai diinput, yaitu data pemeriksaan keselamatan dan keamanan dikawasan bandrara. Proses pengambilan data keselamatan dan keamanan, serta penyampaian informasinya sesuai dengan tujuan sistem. Setelah dilakukan implementasi aplikasi dapat digunakan oleh Dinas Safety \& Risk PT. Angkasa Pura II (Persero) Cabang Bandara Internasional Minangkabau untuk menunjang kinerja perusahaan.

\section{HASIL DAN PEMBAHASAN}

Sebelumnya proses pemeriksaan keselamatan dan keamanan di kawasan bandara pada Dinas Safety \& Risk PT. Angkasa Pura II Cabang Bandara Internasional Minangkabau masih menggunakan formulir chek list, sehingga membutuhkan waktu yang lama, pekerjaan tidak efektif dan efesien. Setelah diterapkannya sistem yang dirancang, maka pemeriksaan keselamatan dan keamanan di kawasan bandara yang dilakukan petugas lebih efektif dan efisien.

a. Use Case Diagram

Use Case mendeskripsikan sebuah interaksi antara satu atau lebih aktor dengan sistem informasi yang akan dibuat. Use case digunakan untuk mengetahui fungsi apa saja yang ada di dalam sebuah sistem informasi dan siapa saja yang berhak menggunakan fungsi-fungsi itu dapat dilihat pada Gambar 1. 


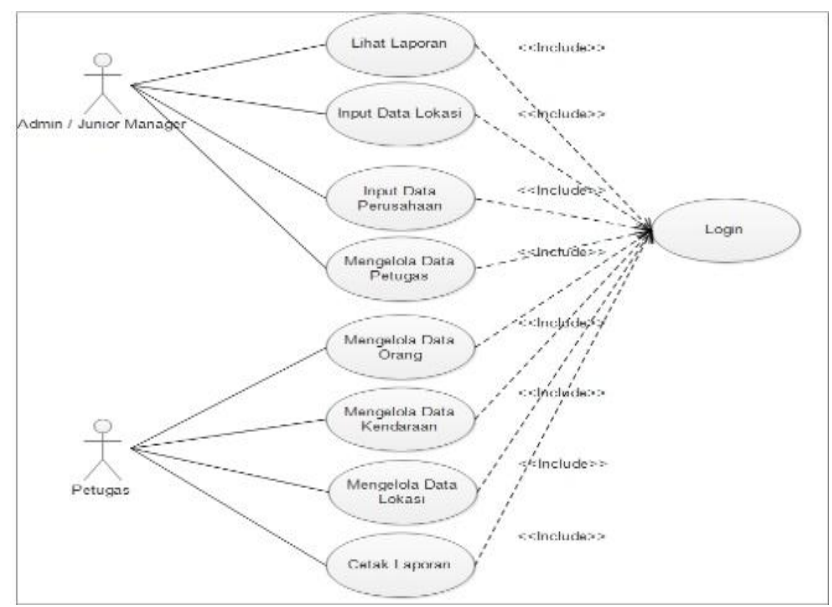

Gambar 1. Use Case Diagram

Penjelasan dari Gambar 1.

1. Untuk masuk ke halaman admin, admin terlebih dahulu login ke aplikasi dengan memasukan username, password dan level admin pada halaman login, dalam hal ini admin bisa menginput data perusahaan, data lokasi, menambahkan petugas, melihat laporan dan setting akun.

2. User (petugas)

Petugas harus terlebih dahulu login ke aplikasi dengan memasukkan username dan password pada halaman login, dalam hal ini petugas dapat menginputkan data orang, kendaraan, lokasi dan melihat laporan serta mencetak laporan orang, kendaraan, dan lokasi.

Adapun bentuk dari aplikasi yang dibuat yaitu:

1. Form Login User

Pada sistem informasi keselamatan dan keamanan di kawasan bandara ini memilki dua hak akses login yaitu admin dan petugas. Halaman Menu Utama Admin

Dari beberapa kegiatan implementasi, maka dapat dilihat dari sistem yaitu menu utama admin merupakan tampilan pertama dari sistem informasi keselamatan dan keamanan di kawasan bandara. Berikut ini dapat dilihat tampilan menu utama admin yang terdiri dari Dashboard, Daftar Perusahaan, Daftar Lokasi, Data Orang, Data kendaraan, Data Lokasi, Log Aktifitas, Petugas dan setting akun yang dapat dilihat pada Gambar 2.

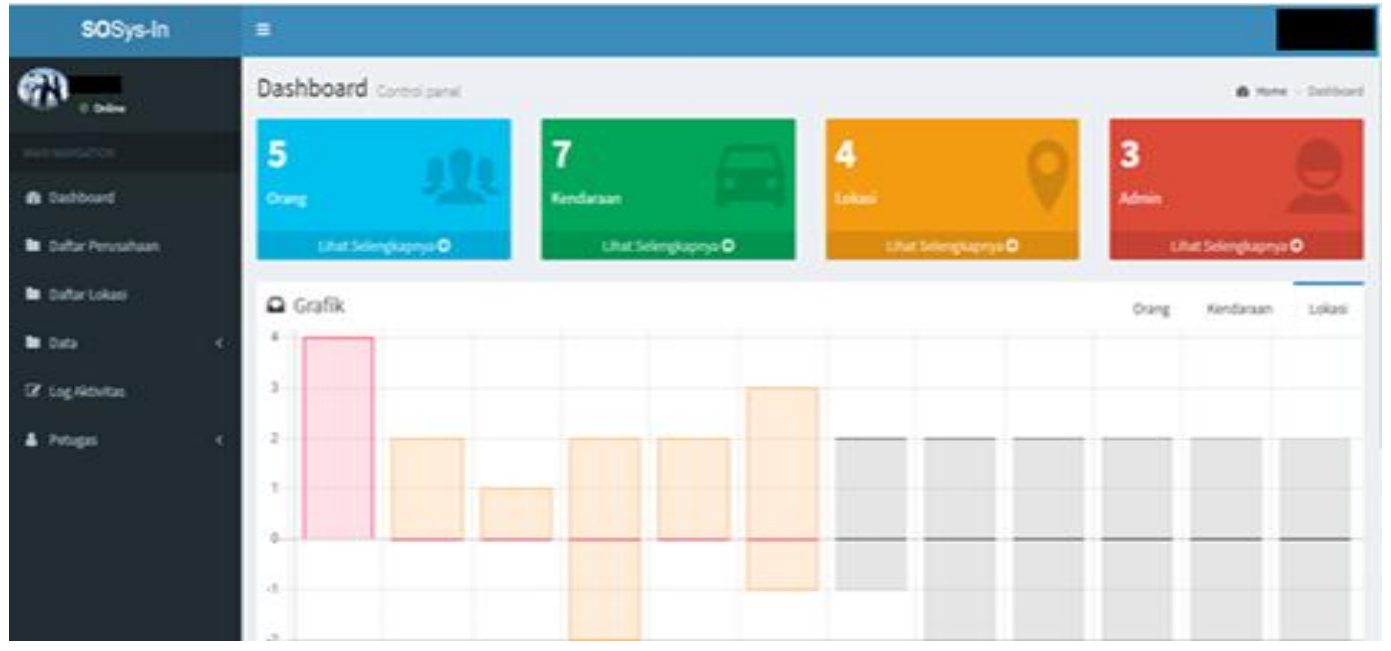

Gambar 2. Halaman Menu Utama Admin 
2. Form Input Data Pemeriksaan Orang

Form ini difungsikan sebagai form input data pemeriksaan orang yang nantinya akan dilakukan pemeriksaan oleh petugas. Form input data pemeriksaan orang dapat dilihat pada Gambar 3.
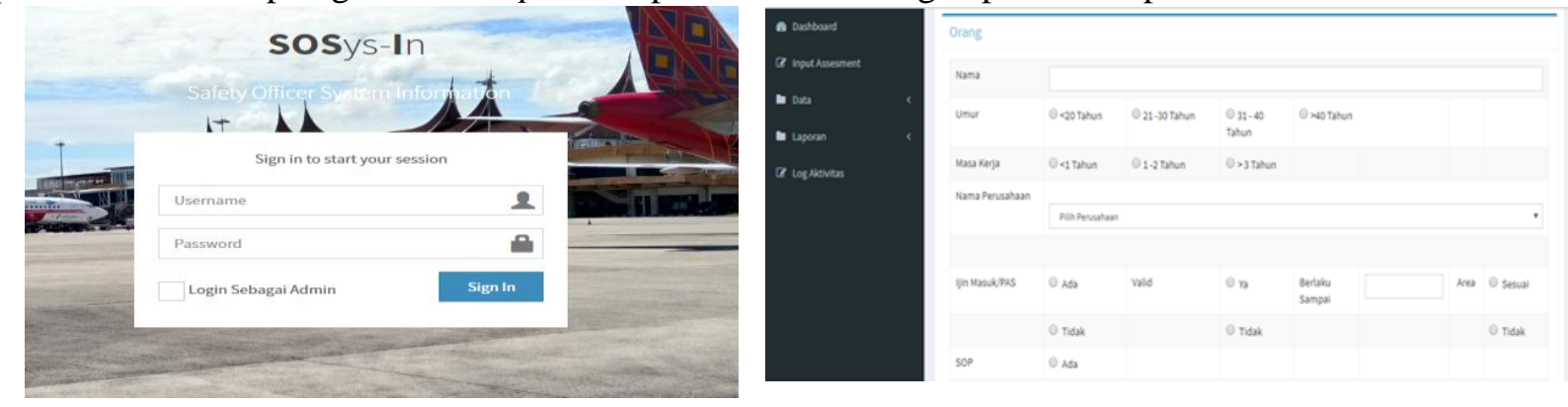

Gambar 3. Form Input Data Pemeriksaan Orang

3. Form Input Data Pemeriksaan Kendaraan

Form ini difungsikan sebagai form input data pemeriksaan kendaraan yang nantinya akan dilakukan pemeriksaan oleh petugas. Form Input

data pemeriksaan kendaraan dapat dilihat pada Gambar 4.

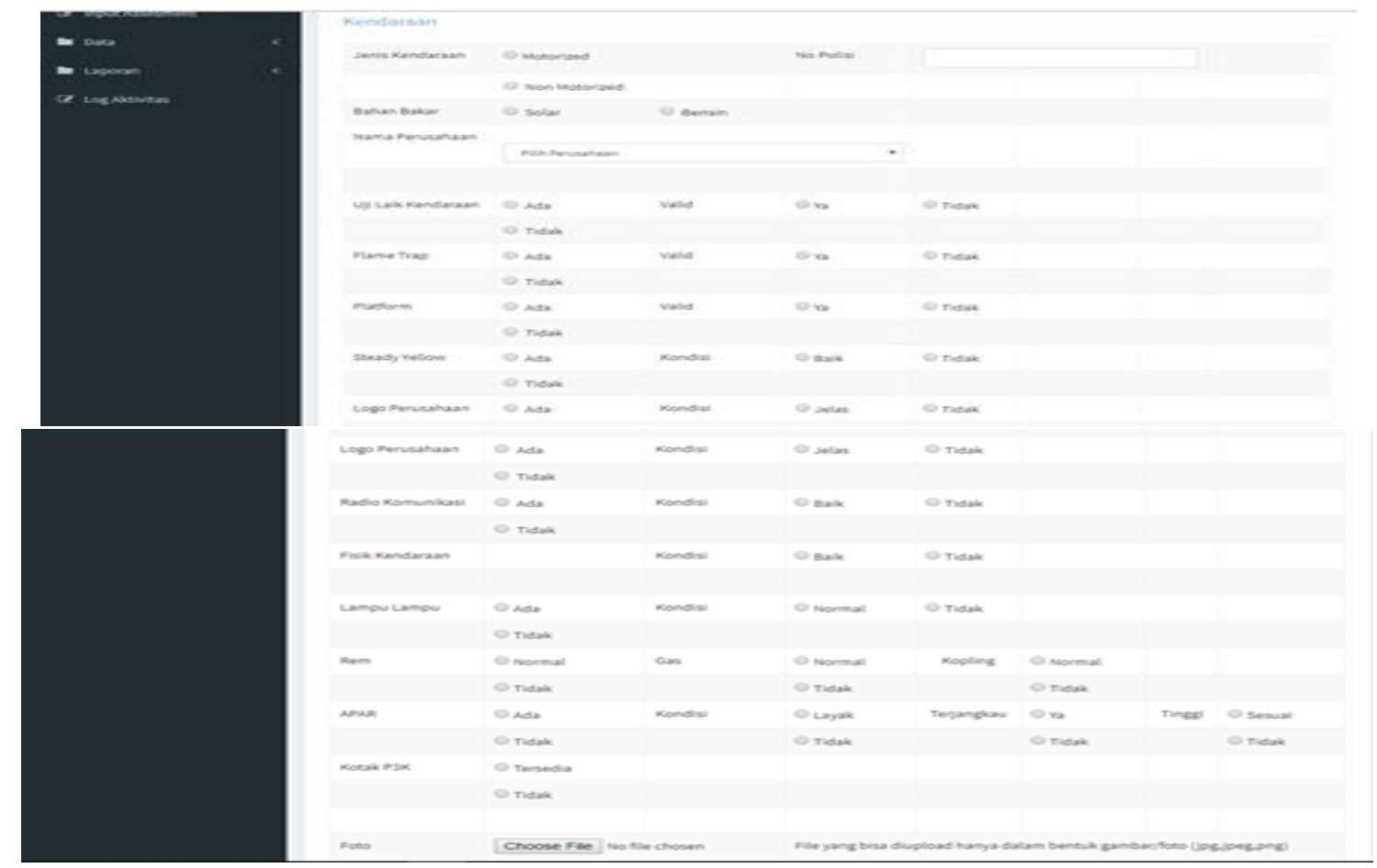

Gambar 4. Form Input Data Pemeriksaan Kendaraan

\section{Form Input Data Pemeriksaan Lokasi}

Form ini difungsikan sebagai form input data pemeriksaan lokasi yang nantinya akan dilakukan pemeriksaan oleh petugas. Form Input Data Pemeriksaan Lokasi dapat dilihat pada Gambar 5. 

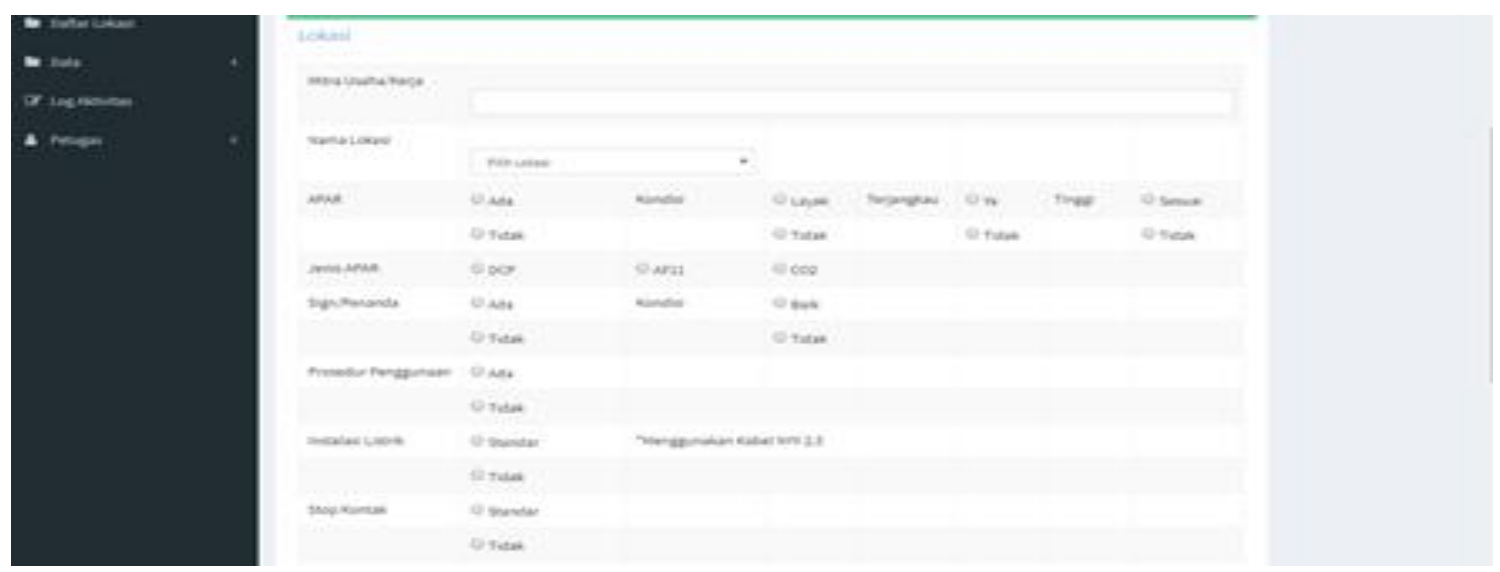

Gambar 5. Form Input Data Pemeriksaan Lokasi

5. List Data Pemeriksaan Orang

List data pemeriksaan orang ini difungsikan untuk melihat data orang yang telah dilakukan pemeriksaan oleh petugas. List data pemeriksaan orang dapat dillihat pada Gambar 6.
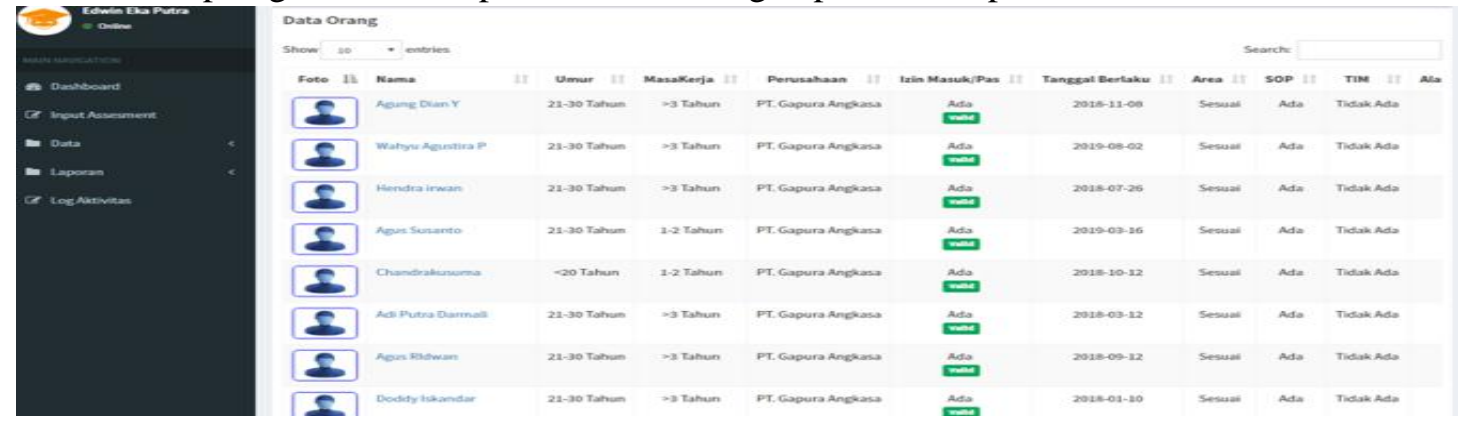

Gambar 6. List Data Pemeriksaan Orang

\section{List Data Pemeriksaan Kendaraan}

List data pemeriksaan kendaraan ini difungsikan untuk melihat data kendaraan yang telah dilakukan pemeriksaan oleh petugas. List data pemeriksaan kendaraan dapat dilihat pada Gambar 7.
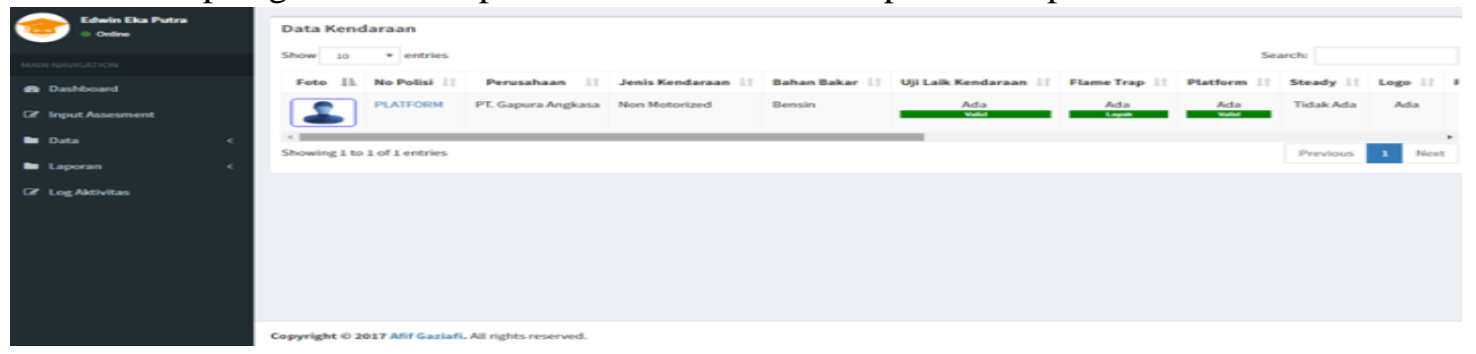

Gambar 7. List Data Pemeriksaan Kendaraan

8. List Data Pemeriksaan Lokasi

List data pemeriksaan lokasi ini difungsikan untuk melihat data lokasi yang telah dilakukan pemeriksaan oleh petugas. List data pemeriksaan lokasi dapat dilihat pada Gambar 8. 

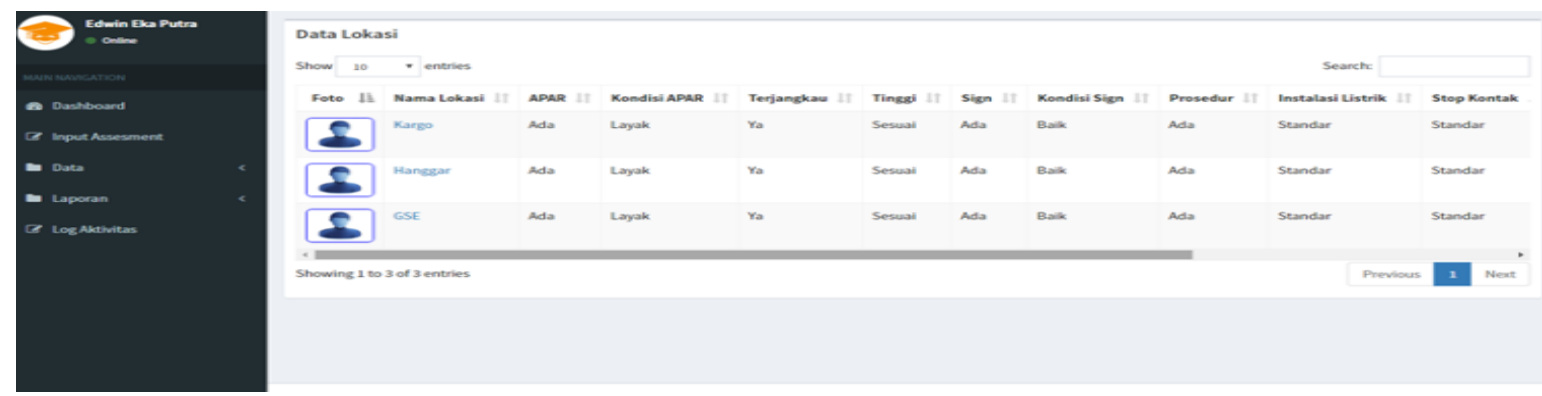

Gambar 8. List Data Pemeriksaan Lokasi

9. List Daftar Lokasi

List daftar lokasi ini difungsikan untuk melihat daftar lokasi yang akan dilakukan pemeriksaan oleh petugas. List daftar lokasi dapat dilihat pada Gambar 9.

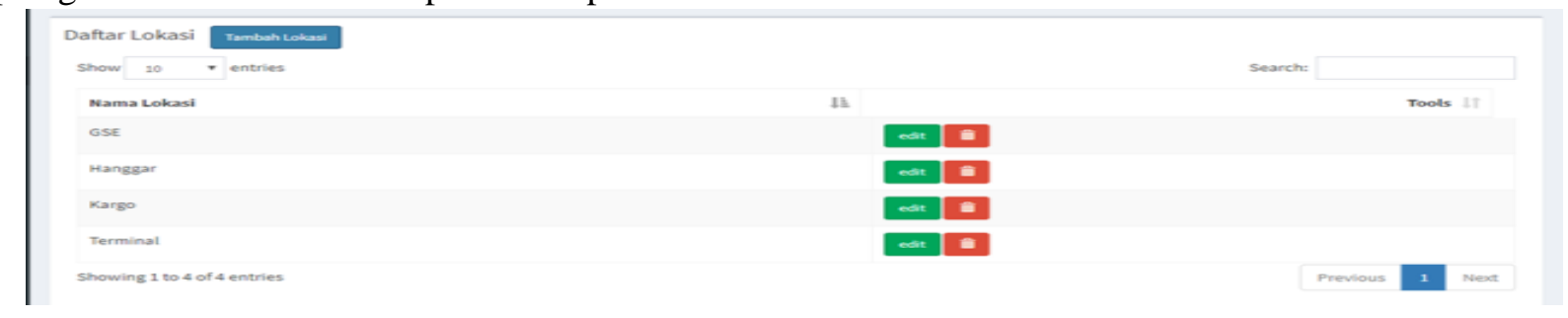

Gambar 9. List Daftar Lokasi

10. Form Tambah Daftar Lokasi

Form tambah daftar lokasi ini difungsikan sebagai form input daftar lokasi yang nantinya akan dilakukan pemeriksaan oleh petugas. Form tambah daftar lokasi dapat dilihat pada Gambar 10.

Tambah Lokasi

Nama Lokasi

Gambar 10. Form Tambah Daftar Lokasi

\section{List Daftar Perusahaan}

List daftar perusahaan ini difungsikan untuk melihat daftar perusahaan yang akan dilakukan pemeriksaan oleh petugas. List daftar perusahaan dapat dilihat pada Gambar 11.

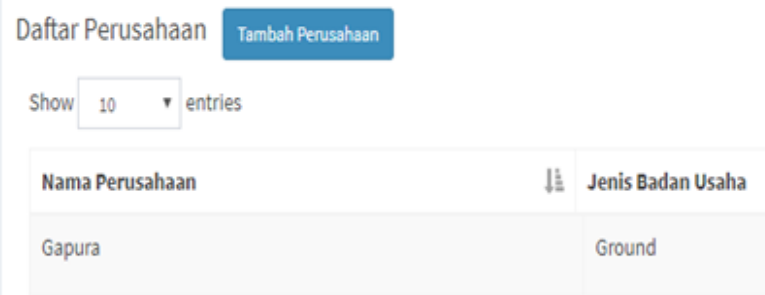

Showing 1 to 1 of 1 entries

Search:

It

edit $\mathbf{A}$

Gambar 11. List Daftar Perusahaan 


\section{Form Tambah Daftar Perusahaan}

Form tambah daftar perusahaan ini difungsikan sebagai form input tambah daftar perusahaan yang nantinya akan dilakukan pemeriksaan oleh petugas. Form tambah daftar perusahaan dapat dilihat pada Gambar 12.

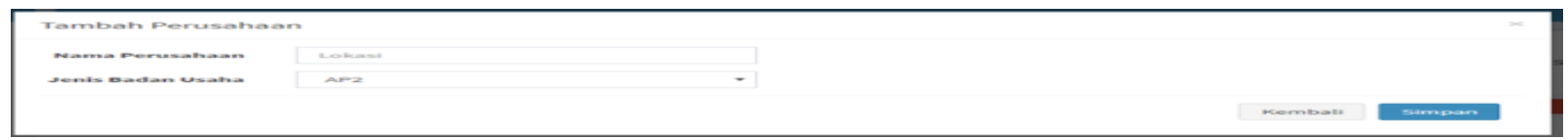

Gambar 12. Form Tambah Daftar Perusahaan

\section{List Data Petugas}

List Data Petugas difungsikan untuk melihat data petugas Safety \& Risk. List Data Petugas dapat dilihat pada Gambar 13.

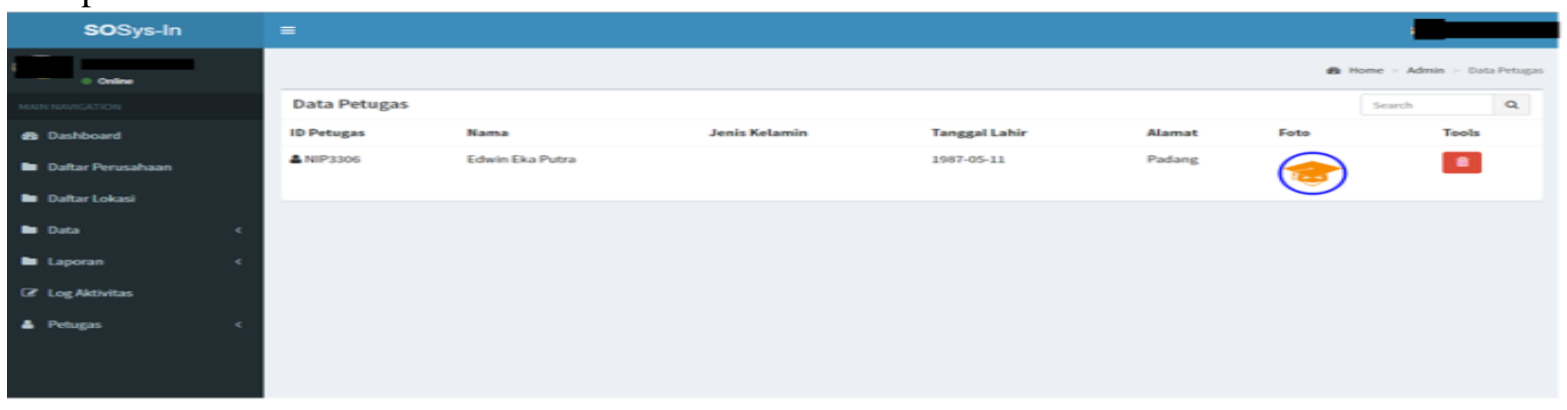

Gambar 13. List Data Petugas

14. Form Tambah Petugas

Form tambah petugas difungsikan sebagai form input menambahkan petugas yang diinputkan oleh admin. Form tambah petugas dapat dilihat pada Gambar 14.
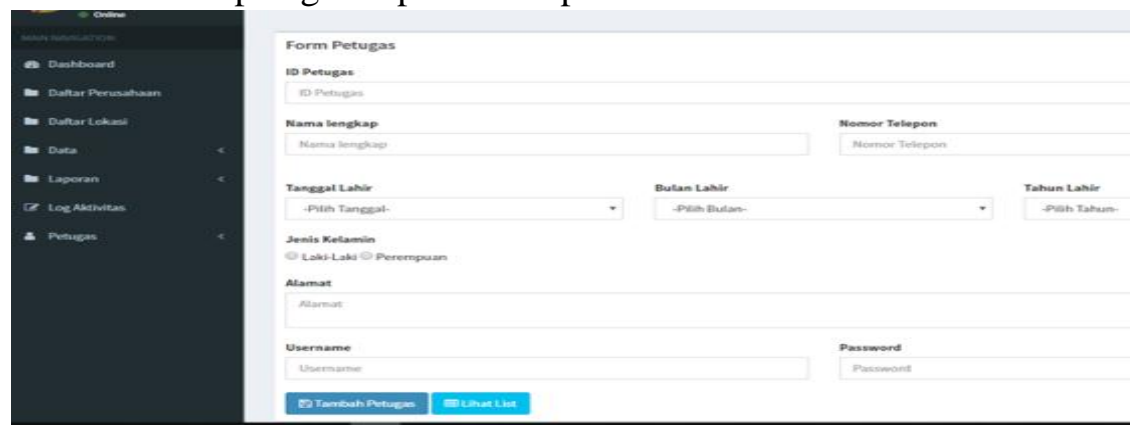

Gambar 14. Form Tambah Petugas

15. Cetak Laporan Orang

Hasil cetak laporan keselamatan dan keamanan orang dapat dilihat pada Gambar 15. 

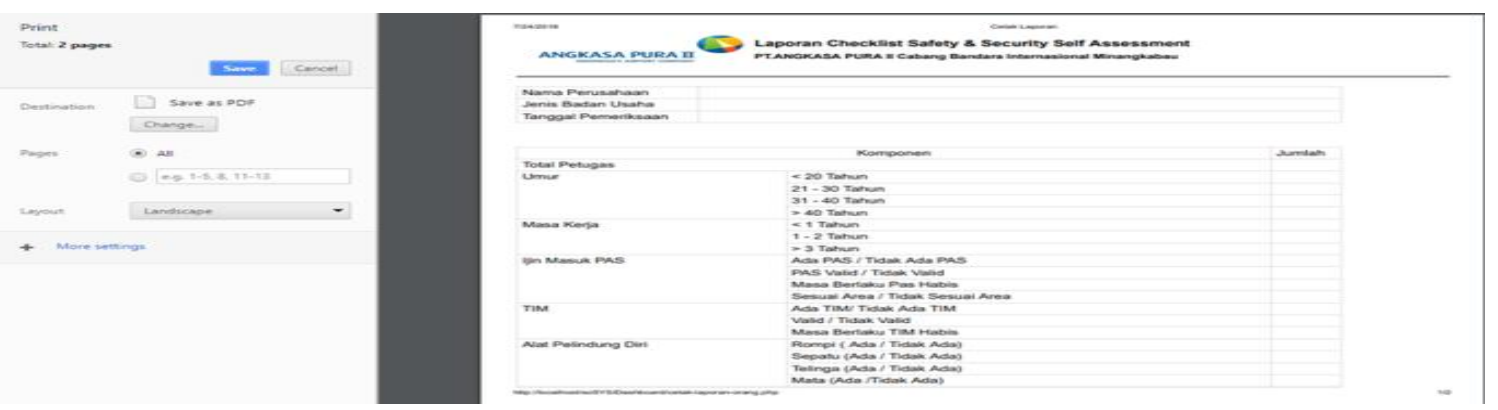

Gambar 15. Cetak Laporan Orang

16. Cetak Laporan Kendaraan

Hasil cetak laporan keselamatan dan keamanan kendaraan dapat dilihat pada Gambar 16.
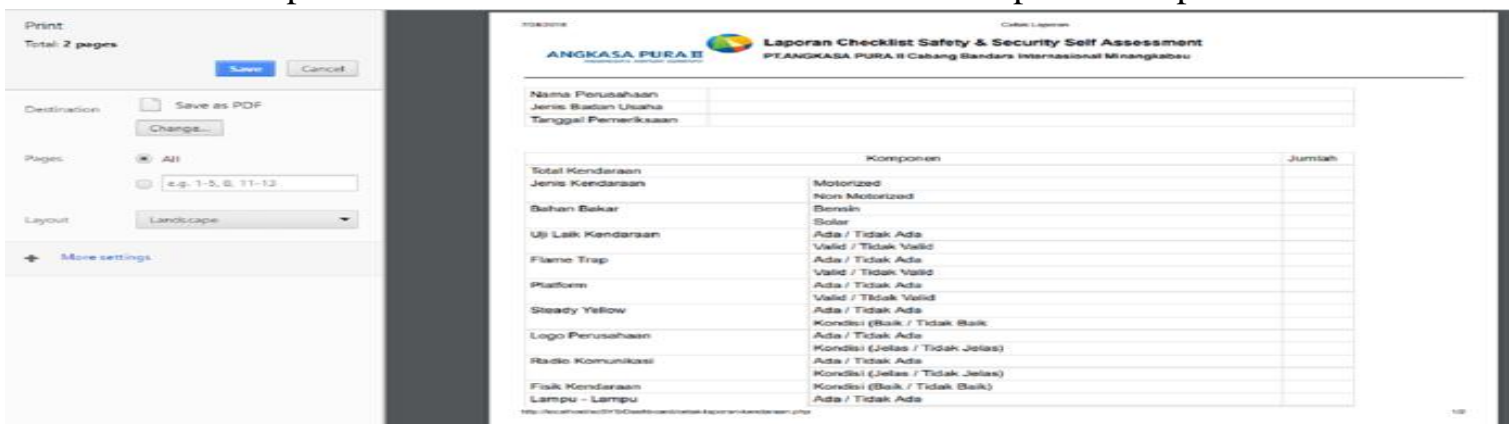

Gambar 16. Cetak Laporan Kendaraan

17. Cetak Laporan Lokasi

Hasil cetak laporan keselamatan dan keamanan lokasi dapat dilihat pada Gambar 17.
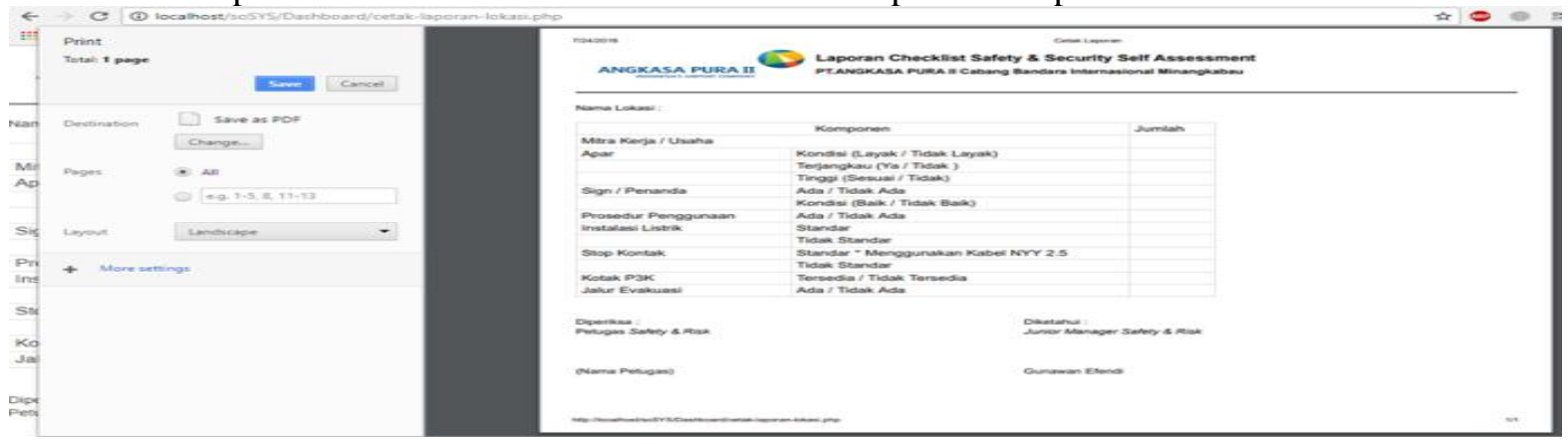

Gambar 17. Cetak Laporan Lokasi

\section{Box Notifikasi}

Box Notifikasi berfungsi untuk memberi notifikasi bahwa ada PAS seseorang yang telah habis masa berlaku. Box Notifikasi dapat dilihat pada Gambar 18. 


\title{
Box Notifikasi
}

\section{Pas Gunawan Efendi Telah Habis!}

\author{
Gambar 18. Box Notifikasi
}

\section{KESIMPULAN}

Berdasarkan hasil dan pembahasan yang telah dilakukan, maka dapat diambil beberapa kesimpulan sebagai berikut:

a. Dengan tersedianya sistem informasi keselamatan dan keamanan dikawasan bandara, petugas dapat melakukan pemeriksaan dengan cepat dan akurat.

b. Dengan tersedianya sistem informasi keselamatan dan keamanan di kawasan bandara, memudahkan petugas dalam melakukan pengecekan masa berlaku PAS bandara, penyimpanan data terintegrasi dengan database, dan petugas dapat melakukan pencarian data dengan cepat.

c. Dengan tersedianya sistem informasi keselamatan dan keamanan di kawasan bandara, dapat menampilkan grafik data keselamatan dan keamanan di kawasan bandara.

UCAPAN TERIMA KASIH

Berisi ucapan terima kasih kepada lembaga LPPM STMIK Indonesia Padang, kepada Ketua STMIK Indonesia Padang dan juga kepada Pimpinan PT. ANGKASA PURA II BANDARA INTERNASIONAL MINANGKABAU yang telah membantu dalam pelaksanaan penelitian tersebut.

\section{REFERENSI}

1. Abdul, Kadir dan Terra Ch. Triwahyuni (2013). Pengantar Teknologi Informasi Edisi Revisi. Yogyakarta: Andi Offset.

2. Eka Putra, Ilham. (2014). Desain \& Pemograman WEB. Yogyakarta: Leuti Kaprio

3. Fathansyah. (2012). Basis Data. Bandung: Informatika

4. Hamim, Tohari. (2005). Analisis Serta Perancangan Sistem Informasi Melalui Pendekatan UML. Yogyakarta: Andi Offset.

5. Kadir, Abdul. (2008). Belajar Database Menggunakan MySQL. Yogyakarta: Andi Offset

6. Kadir, Abdul. (2014). Pengenalan Sistem Informasi. Yogyakarta: Andi Offset

7. Kusrini. (2007). Konsep dan Aplikasi Sistem Pendukung Keputusan. Yogyakarta: Andi Offset

8. Madcoms. (2016). Pemrograman PHP dan MySQL untuk Pemula. Yogyakarta: Andi Offset

9. Rosa A. S. dan M.Shalahudin. (2014). Rekayasa Perangkat Lunak Terstruktur dan Berorientasi Objek. Bandung: Informatika Bandung. 
10. Rosa A. S. dan M.Shalahudin. (2016). Rekayasa Perangkat Lunak Terstruktur dan Berorientasi Objek. Bandung: Informatika Bandung.

11. Sutabri, Tata. (2012). Konsep Sistem Informasi. Yogyakarta: Andi Offset

12. Tantra, Rudy. (2012). Manajemen Proyek Sistem Informasi. Yogyakarta: Andi Offset

13. Ulil A. Fida Husain, dkk. Perancangan Sistem Informasi Berbasis Komputer Untuk Manajemen Perawatan Fasilitas Industri Manufaktur Kapal. Jurnal Sistem Informasi (JSI) Volume 5 Nomor 2, April 2016, ISSN: 2337-3539 